\title{
Annulotrematoides bryconi sp. n. (Monogenea: Dactylogyridae) parasitic on Brycon cephalus (Osteichthyes: Characidae) from Brazil
}

\author{
Ana Maria Cuglianna ${ }^{1}$, Nelson da Silva Cordeiro ${ }^{1}$ and José Luis Luque ${ }^{2}$ \\ ${ }^{1}$ Departamento de Parasitologia, Instituto de Biologia, Universidade Estadual de Campinas (UNICAMP), Caixa Postal 6109, \\ CEP 13083-970, Campinas, SP, Brasil; \\ ${ }^{2}$ Departamento de Parasitologia Animal, Universidade Federal Rural do Rio de Janeiro, Caixa Postal 74.508, CEP 23851-970, \\ Seropédica, RJ, Brasil
}

Key words: Monogenea, Dactylogyridae, Annulotrematoides bryconi, Brycon cephalus, Characiformes, pisciculture, Brazil

\begin{abstract}
Annulotrematoides bryconi sp. n. is described and illustrated from specimens collected from gills of characiform fish, Brycon cephalus (Günther, 1869), in pisciculture ponds from Pirassununga, São Paulo, Brazil. Diagnostic characters of the new species are the tegument of trunk showing annulations, except on the cephalic regiona, and copulatory complex comprising sclerotized male copulatory organ coiled in $1 \frac{1}{2}$ rings. This is the first record of monogeneans parasitic on the gills of $B$. cephalus.
\end{abstract}

Species of Brycon Müller et Troschel are fishes with significant importance as food resource and they have great potential for intensive pisciculture in the Amazonian basin (Romagosa et al. 2002). Studies on monogeneans parasitic on these fishes from Neotropical Region have been restricted to two host species: Brycon melanopterus (Cope, 1872) from Brazil with species of the dactylogyrid genera Anacanthorus Mizelle et Price, 1965; Jainus Mizelle, Kritsky et Crane, 1968; Tereancistrum Kritsky, Thatcher et Kayton, 1980 and Trinibaculum Kritsky, Thatcher et Kayton, 1980; and Brycon americanus peruanus Müller et Troschel, 1844 from Peru with an undetermined gyrodactylid species of Anacanthocotyle Kritsky et Fritts, 1970 (Kritsky et al. 1979, 1980, Jara 1986).

In this report, a new species of dactylogyrid parasitic on Brycon cephalus (Günther, 1869) from Brazil is described and illustrated.

\section{MATERIALS AND METHODS}

The monogeneans studied are part of the material collected from 72 specimens of $B$. cephalus from pisciculture ponds of CEPTA (Centro Nacional de Pesquisas de Peixes Tropicais) from Pirassununga, State of São Paulo, Brazil during April 1999 to March 2000. The fish measured 30-38 cm (mean = $34.9 \pm 2.4 \mathrm{~cm})$ in standard length and weighed $321-512 \mathrm{~g}$ $($ mean $=406.2 \pm 61.7 \mathrm{~g})$. The monogeneans were removed from the gills of hosts with a 1:4000 formalin solution, fixed in $5 \%$ formalin and stored in $70 \%$ ethanol. The parasites were stained with Gomori's trichrome and mounted in Canada balsam and some specimens were mounted in Gray and Wess' medium (Humason 1979) for study of sclerotized structures. The measurements are in micrometres $(\mu \mathrm{m})$; the mean is followed by the range and number of specimens measured (n) in parentheses. The illustrations were made with the aid of a drawing tube mounted on a Hund Wetzlar H-600 phase contrast microscope. The numeration of the hook pairs follows Mizelle (1936). The holotype and some paratypes were deposited in the Helminthological Collection of the Instituto Oswaldo Cruz (CHIOC), Rio de Janeiro, Brazil, and other paratypes in the Collection of the Natural History Museum of the University of Campinas (UNICAMP), São Paulo, Brazil.

\section{RESULTS}

PolyonCHOINEA Bychowsky, 1937

D a c t y log y rida e Bychowsky, 1933

Ancyrocephalinae Bychowsky, 1937

Annulotrematoides bryconi sp. n.

Figs. 1-8

Description (based on 19 specimens). Body 376 (264-495, $\mathrm{n}=19)$ long, greatest width $127(77-165, \mathrm{n}=$ 19). Cephalic lobes developed, 3 pairs of head organs. Accessory eye granules oval, not scattered in cephalic area. Pharynx oval, $19(18-23, \mathrm{n}=9)$ in diameter; oesophagus elongate. Peduncle elongate. Haptor subhexagonal, 48 (38-66, $\mathrm{n}=19)$ long, $103(60-181, \mathrm{n}=19)$ wide. Similar anchors. Ventral anchor $37(30-44, \mathrm{n}=6)$ long, base $11(8-15, \mathrm{n}=4)$ wide; dorsal anchor 37 (36$39, \mathrm{n}=6)$ long, base $14(11-16, \mathrm{n}=6)$ wide; with elongate superficial root, short broad deep root, curved shaft, recurved point and anchor filaments. Ventral bar 48 (38-57, $\mathrm{n}=7$ ) long, plate-like, with slightly enlarged ends and medial ridge; dorsal bar $44(33-51, \mathrm{n}=5)$ long, medial bend. Hooks similar; each with erect thumb, shaft and evenly curved point; proximal half of shank dilated. Hook pairs 1, 5, $18(18-19, \mathrm{n}=3)$ long; pairs 2, 3, 4, 6, 7, $23(20-26, \mathrm{n}=4)$ long; FH loop

Address for correspondence: A.M. Cuglianna, Departamento de Parasitologia, Instituto de Biologia, Universidade Estadual de Campinas (UNICAMP), Caixa Postal 6109, CEP 13083-970, Campinas, SP, Brasil. Phone: ++55 19378 86 280; Fax: ++55 19 378 86 282; E-mail: cugliana@yahoo.com.br 


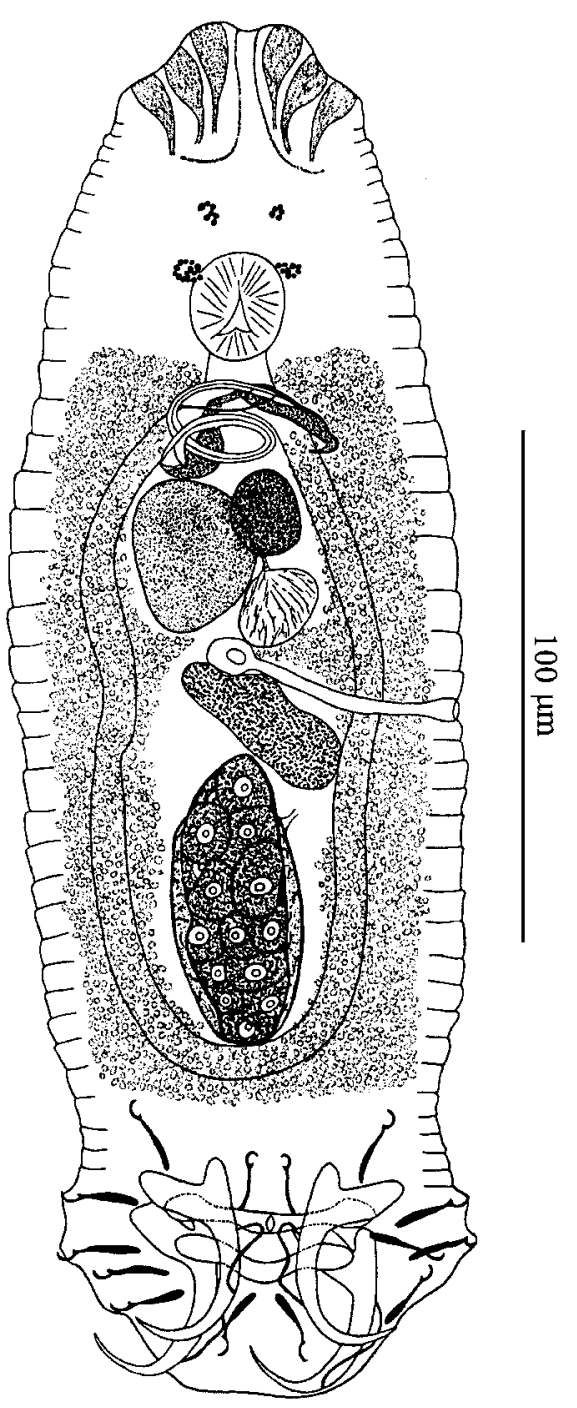

Fig. 1. Annulotrematoides bryconi sp. n. Composite drawing of whole mount (ventral view).

extending to just short of union of shank subunits. Male copulatory organ sclerotized, a coiled tube with approximately $1 \frac{1 / 2}{2}$ counter-clockwise rings; proximal ring $47(33-60, n=10)$ in diameter. Accessory piece articulated, acute terminally, with variable flattened projection near midlength. Copulatory ligament passing within proximal ring of male copulatory organ. Testis dorsal to germarium, $59(51-63, \mathrm{n}=7)$ long; vas deferens elongate; seminal vesicle developed, suboval; two saccate prostatic reservoirs. Germarium elongate, $69(59-78, \mathrm{n}=7)$ long, $19(15-23, \mathrm{n}=7)$ wide. Vagina subspherical, with thick proximal wall, opening into large central seminal receptacle. Vitellaria lateral. Uterus and eggs not observed.
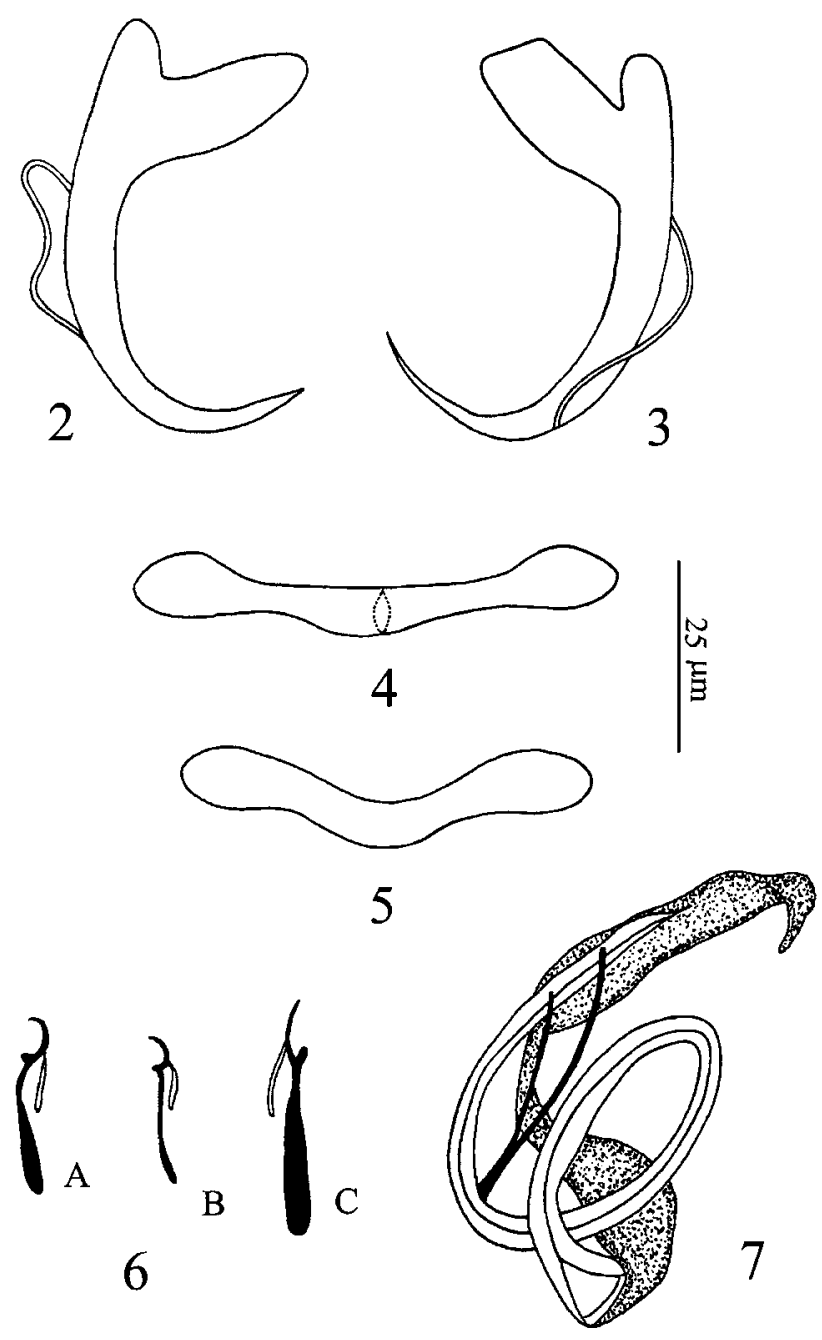

Figs. 2-8. Annulotrematoides bryconi sp. n. Fig. 2. Ventral anchor. Fig. 3. Dorsal anchor. Fig. 4. Ventral bar. Fig. 5. Dorsal bar. Fig. 6. Hooks. A - hook pair 1; B - hook pair 5; C - hook pairs 2, 3, 4, 6, 7. Fig. 7. Male copulatory organ. Figs. 2-7 drawn to same scale.

T y p e h o s t : Brycon cephalus (Günther, 1869) (Characiformes: Characidae).

Site of infection: Gills.

T y p e 1 o c a 1 i t y : Ponds in Pirassununga, State of São Paulo, Brazil.

S p e c i m e n s s t u d i e d : Holotype, CHIOC 36276; six paratypes, CHIOC 36272, 36273a-b, 36274a-b, 36275; four paratypes, UNICAMP 12, 13, 14, 15.

E t y m o log y: The specific epithet refers to the genus of the type host. 


\section{DISCUSSION}

Because of the presence of annulations in the tegument, by the vaginal aperture on the left margin of trunk and by the position of the gonads (testis dorsal to germarium), the new species can be included in Annulotrematoides Kritsky et Boeger, 1995. The only other known species of Annulotrematoides is A. amazonicus Kritsky et Boeger, 1995 parasitic on Psectrogaster rutiloides (Kner) from Manaus, Brazil. A related genus Annulotrema Paperna et Thurston, 1969 includes some species from African and European freshwater fishes. According to the original diagnosis (Paperna and Thurston 1969), the vaginal aperture of Annulotrema is on the left margin of trunk. However, Kritsky and Boeger (1995) stated, after examination of specimens of two unidentified Annulotrema species from Togo, that the vaginal aperture opens on the right margin of trunk. Thus, Annulotrematoides can be separated from Annulotrema by the vaginal aperture on the left margin of trunk. Another difference between Annulotrematoides and Annulotrema is the position of the gonads (testis dorsal to germarium in Annulotrematoides, dorsoposterior in Annulotrema).

Annulotrematoides bryconi can be separated from $A$. amazonicus by the large extension of the annulations along the trunk with exception of cephalic region only (annulations are restricted to posterior half of trunk in $A$. amazonicus) and by the coiled male copulatory organ (copulatory organ is not coiled in A. amazonicus).

Acknowledgements. We thank Dr. Paulo S. Cecarelli (CEPTA) for providing and identifying the fishes studied. A.M. Cuglianna was partially supported by a student fellowship from the Coordenação de Aperfeiçoamento do Pessoal do Ensino Superior (CAPES). J.L. Luque was supported by a fellowship from CNPq (Conselho Nacional de Pesquisa e Desenvolvimento Tecnológico).

\section{REFERENCES}

HUMASON G.L. 1979: Animal Tissue Techniques. W.H. Freeman Co., San Francisco, USA, 661 pp.

JARA C.A. 1986: Finding of Gyrodactylus sp. and Anacanthocotyle sp. (Monogenea, Gyrodactylidae) in fishes from the Moche River, Trujillo, Peru. Hidrobios 10: $8-16$.

KRITSKY D.C., BOEGER W.A. 1995: Neotropical Monogenoidea. 26. Annulotrematoides amazonicus, a new genus and species (Dactylogyridae: Ancyrocephalinae), from the gills of Psectrogaster rutiloides (Kner) (Teleostei: Characiformes: Curimatidae) from the Brazilian Amazon. Proc. Helminthol. Soc. Wash. 108: 528-532.

KRITSKY D.C., THATCHER V.E., KAYTON R.J. 1979: Neotropical Monogenoidea. 2. The Anacanthorinae Price, 1967, with the proposal of four new species of Anacanthorus Mizelle \& Price, 1965, from Amazonian fishes. Acta Amazon. 9: 355-361.
KRITSKY D.C., THATCHER V.E., KAYTON R.J. 1980: Neotropical Monogenoidea. 3. Five new species from South America with the proposal of Tereancistrum gen. $\mathrm{n}$. and Trinibaculum gen. n. (Dactylogyridae: Ancyrocephalinae). Acta Amazon. 10: 411-417.

MIZELLE J.D. 1936: New species of trematodes from the gills of Illinois fishes. Am. Midl. Nat. 17: 785-806.

PAPERNA I., THURSTON J.P. 1969: Annulotrema n. gen., a new genus of monogenetic trematodes (Dactylogyridae, Bychowski, 1957) from African Characin [sic] fish. Zool. Anz. 182: 444-449.

ROMAGOSA E., NARAHARA M.Y., AYROSA L.M.S., BORELLA M.I., FENERICH-VERANE N. 2002: Reproductive cycle of male matrinxã Brycon cephalus (Günther, 1869) (Teleostei: Characidae). Brazil. J. Morphol. Sci. 17: 101-105.

Accepted 14 October 2003 